UDC 339.138

JEL Classification: M10, M31

http://doi.org/10.21272/mmi.2019.2-16

Muhammad Taqi,

Ph.D., Izmir University of Economics, Turkey

Nilgun Gurkaynak,

Izmir University of Economics, Turkey

Mehmet Gencer,

Associate Professor, Izmir University of Economics, Turkey

\title{
MARKETING CONCEPT EVOLUTION: A BIBLIOMETRICS CO-OCCURRENCE ANALYSIS
}

Abstract. This study examines how scholarly research on marketing has evolved since the beginning of the millennium, and how the marketing academia has responded to the call for reform in 2006. The main purpose of the study is to find out the directions in which the marketing academia was before the call of reform and how/if the direction changed after the call of reform and has/has not evolved the marketing concept. The call for a reform in marketing academia has pointed out the number of issues which marketing has been facing, yet no proper actions were taken by the scholarly body in the past. This study investigates the topics of study which were in focus before the call of reform in comparison to the topics which were emphasized on after the call. In order to understand if changes took place, the authors used a bibliometrics approach known as co-word analysis. VOSviewer software was used for carrying out co-word (keyword co-occurrence) analysis. The data for the study was attained via the SCOPUS database. The body of literature under review is comprised of a corpus of 3,618 articles from top 11 marketing journals according to the citation index of SCOPUS database. In addition to general marketing journals, the list includes journals from some of the specialized areas such as channel and supply management, consumer behaviour, interactive and international marketing. The keyword analysis sought to identify trends in marketing research and compared findings to the call of a possible reform in the field of marketing as presented in the 2006 compilation of articles written by over 40 well-known scholars in the marketing discipline edited by Sheth and Sisodia. Through keyword analysis, the authors developed eight themes to which the keywords belonged. The keyword analysis empirically confirms and theoretically proves there is a change in trend since the call of reform which shows the changes taking place in the evolution of marketing concept. A lot of new topics appeared which the call had emphasized on, lots of the topics were left behind, and several were carried on after the call. Based on the results of the analysis we hold that the call for the reform was responded by the academia to a certain extent. These results of the study are useful to see how the academia responded to call for reform and to see the changes brought in the marketing research since the call for reform. Alongside, to the knowledge of authors, there currently is no study to see whether the call for reform by the top marketing scholars was given any importance or not, or whether if it brought any changes.

Keywords: bibliometrics, co-occurrence analysis, evolution of marketing, marketing reform, marketing.

Introduction. As the editors Sheth and Sisodia, (2006a) of the book mention that marketing has been coming up with many ideas and ways through which it was able to attract consumers into buying products, but today the bag of tricks has fallen either empty, useless, dangerous for marketers and the firms in the contemporary business world. Marketing has said to be going in the downward direction for the past two decades which has led companies around the world to take away its importance and replace it from their main decision-making departments. Marketing departments in the companies are no longer given the importance which it once held in the past, now marketing is looked like a practice which only brings high costs to the firm without bringing any returns. Sheth and Sisodia (2006a) pointed out three problems which the marketing faces today. Firstly, marketing activities carried out today are unethical, where the marketers tend to take advantage of the consumersю Secondly, marketing activities are carried out in a manner so that the consumers tend to take advantage of the company's poor marketing strategies and this is known as «dumb marketing». Lastly, certain marketing activities are

Cite as: Taqi, M., Gurkaynak, N., \& Gencer, M. (2019). Marketing Concept Evolution: a Bibliometrics Co-occurrence Analysis. Marketing and Management of Innovations, 2, 185-197. http://doi.org/10.21272/mmi.2019.2-16 
«wasteful» because they do not benefit either the company nor the consumer. The number of scholars has pointed out the fact that marketing is need of new tools which would lead marketing to its original state as it once held (Amber, 2006; Keller and Kotler, 2006; Sheth and Sisodia, 2006b; Varadarajan, 2006). Marketing not only needs new tools but also needs to reshape its ways of carrying out marketing practices due to the change in consumer thinking. New consumers have access to information/are able to make an informed decision and are able to easily catch the marketing practices which leads to loss of loyalty and reliability on the firm. Consumers can easily access information from the internet and compare it to the marketed information (Smith, 2006). Innovation and development in the technology have no doubt provided marketers with new ways of practising marketing but it has also made it difficult for the marketing practices to be effective. The main objective of this study is to understand whether the calls for a possible reform in marketing has been responded by academic research and has evolved the marketing concept in the following areas:

- Insight-centric marketing organization (ICO).

- Relationship of marketing with other organizational functions.

- Consumer resistance to marketing/excessive marketing spending.

- Accountability of marketing (ROMI).

- Future of marketing/marketing paradigms/mental models.

- Marketing technology.

- Marketing education.

- Societal impact and sustainability through marketing.

Following are the eight main themes which were discussed in «Does Marketing Need Reform» book by Sheth and Sisodia (2006). This study examines whether this book has changed the direction of marketing scholarly research. Insight-centric marketing organization (ICO): Consumers are not happy because they are being marketed products/services which do not mean anything to them. The concept of marketing has to change. As of now, Smith (2004a) explains the marketing process as «dominance and control are enforced by practising and policing marketing as a one-way street. Marketers control the process and make all of the decisions. Consumers take their cues from marketers. Marketers produce. Consumers buy. Marketers listen and observe. Consumers view and react. Everything starts with marketers and then goes in one direct-from marketer to consumers» (p. 22). He proposed to change the concept of marketing and the main concept of the organization as a whole. Marketing organizations need to be more consumer-centric than organization-centric. «The new organization to complement the new tool is the insight-centric marketing organization (ICO), in which everything follows from insights. Processes and databases have no standing or value apart from insights. In an ICO, processes are not important in and of themselves but only as they fulfil or satisfy what insights reveal about consumers' needs, preferences, and attitudes. An ICO puts the consumer insights at the centre of everything» ( $p$. 24). Marketing has to become more consumer-centric and leave behind the traditional marketing practices of being process-centric.

Relationship of marketing with other organizational functions: marketing was a function for firms which brought in a great number of revenues, made the brands to be known all over the world, made loyal customers, and overall was the leading function of the firm. Unfortunately, those days are far gone, the marketing function has started to become marginalized in many firms in the U.S. and Europe. According to Pfeffer (1994) in the U.S., there is an over 65 per cent difference in the compensation of a marketing executive and of finance executive and over 90 per cent difference from a manufacturing executive. Whereas, in British companies marketing function is looked upon as just for advertising and promotions (Shipley, 1994). And when it comes to B2B companies, marketing is just above the human resources function (Meldrum and Palmer, 1998). Marketing officers also lack the seat at the big table, in the U.S. only one firm out of top 20 firms of Fortune 500 has a chief marketing officer (Melkman, 2004), 
and in Britain, only 5 companies have a board-level position out of top 100 companies (Simms, 2003). This indicates the respect and importance of marketing as a function is being given in the firms today. Still, there is a number of CEOs who understand the importance of marketing function and are keep marketing function as a vital function within the firm. They also «want marketers to become full partners, understand the whole business, and come up with ideas linked to driving profits» (Lewis, 2002, p. 3). Marketing has very weak relations with the other functions of the firm, especially with finance (Sheth, 2006). Therefore, marketing must involve itself in the other functions of the firm by being a part of them.

Consumer resistance to marketing/excessive marketing spending: consumers from the beginning had some sort of resistance towards marketing, along with this they have created love/hate relationship towards marketing as well. According to Smith (2006), the resistance towards marketing is increasing and now much emphasis has been given to this phenomenon. The study conducted by Yankelovish Partners (2004) showed that $61 \%$ of the respondents had said that marketing and advertising had gotten out of control. Sixty per cent of the respondents had shown an increase in negative feelings towards marketing and increase comparing to the past few years. And $45 \%$ of the respondents said the amount of marketing they are exposed to on a daily basis detracts them from their daily life experience. The study showed that overall respondents had a negative view towards marketing and therefore were resisting towards it. Various studies have shown that on average a consumer is exposed to 10,000 brand logos, ads, advertisements and promotions daily (Smith, 2004b). Smith (2006) noted, «the root of resistance to marketing is not about bad marketing but the basic way in which marketing works. The tactics of domination, saturation, and intrusiveness are standard marketing practices. Yet these tactics are the very things that consumers dislike the most, so consumer resistance is symptomatic of the current marketing model».

Accountability of marketing (ROMI). Winer (2006) addresses to the issues of accountability in marketing by mentioning that he is «in agreement with the thesis that marketing does not have ears of senior management and corporate boards. That is because we have not marketed marketing very well, that is, the enemy is us» (p. 79). Various functions are carried out by the marketing department of a firm which must be accounted for. The finance department of the firm should not be held accountable for the accountability of the expenditure of marketing activities rather it should be the marketing people who should be doing it (Winer, 2006). There seems to question which is yet to be answered on how to evaluate the performance of marketing and its accountability. As noted by Stewart (2006), «marketing has also done a poor job of quantifying its contributions. While there is little debate about the value of a brand, the economic value of a brand and the return on marketing investments required to create that brand have not been defined well by the discipline. The same problem exists with respect to other marketing activities. Even as other business functions have documented economic returns in response to demands for greater accountability, marketing has been very slow to embrace the need for accountability and quantification of return on investment in marketing» (p. 85). Therefore, marketing has to find a way to show its accountability for the investment which it uses for carrying out its activities.

Future of marketing/marketing paradigms/mental models. One question which must be considered with great emphasis is «Where is marketing as a discipline going?» because number of scholars have called for a reform denoting that marketing is need of a change (Johansson, 2006; Malhotra et al., 2006; Wind, 2006). Whereas, Brown (2006) points out that marketing is too big to be reformed and that «it does not need a reform; it needs restraint». Urban (2006) in his paper states «what is needed is a new paradigm for marketing", though he does not propose one. He believes that trust and customer advocacy is the key for marketing to regain its importance. Along with Brown et al. (2006) have also called for a paradigm shift where they propose «from marketing to the market». The shift is needed due to the global economic systems, the global industrial economy, and the changing nature of macroorganizational structures. Winer (2006) believes that there is a need for change in the mental models of 
marketing. Agreeing with him is Wind (2006) whose paper titled «Challenging the Mental Models of Marketing» discusses that new mental models of marketing are needed due to the changing business environment. Even earlier marketing has changed depending on the way business was conducted, how markets were changed and how consumers acted and reacted to the marketing practices. As today, consumers have become more and more educated and well aware of how the marketers tend to trick them, there is a need for marketing to change its base (mental models) and bring changes to how marketing is practised. Developments in information and communication technologies have been affecting marketing practice to great extent. Yet, marketing practices are based on the traditional model where marketers controlled the power (Smith, 2006). Consumers are making use of the technology as much as possible to resist marketing today, they are no longer dependent on marketers to give them information because the information is just a click/touch away. As of the marketers, they have abused every single technological tool which they were given hence decreasing their effectiveness (Seth et al., 2006). They point out the dilemma which marketing faces are of «commons», which is explained as «many people use a common resource, the resource gets overused and ultimately destroyed» (p. 29) and this is where marketing loses the attention of consumers by overgrazing them with the same tool over and over again (Sisodia \& Backer, 2004). As marketers today have put too much emphasis on online marketing by leaving every web page and every app on smartphones full of ads, it seems as if marketers do not understand the dilemma which marketers are in. Where is this marketing technology leading marketing to? Marketing education is provided in university levels all over the world and education facilities play an important role in shaping the marketing discipline. Marketing education just consists of the basics which start off from the four Ps. Not all universities provide courses on consumer behaviour or even the ethics of marketing (Chipp et al., 2006). They also point out that «Much focus has been on content rather than process» and «marketing education overall lacked focus on the process of innovation and risk management», which shows that only information related to marketing concept is given in the classroom and the process of how marketing practices are actually carried out is left out. Raju (2006) in his study has mentioned that PhD students of marketing should be provided with both practical experience and academic because this would enhance their ability to know how marketing practices take place and how they could be improved through academic research. Therefore, it is important that marketers be provided hands-on experience before they could start their career so that they are able to develop strategies, make innovative marketing tools and manage risks which marketing faces.

Societal impact and sustainability through marketing: marketing without a doubt has an impact on the societies all over the world and the impact which it has left great marks. Marketing has also helped societies by bringing the concept of sustainability. Forever since it can be remembered marketing has been responsible for the standard of living of societies all across the world. Berry and Mirabito (2006) state «Marketers have influenced the creation of myriad goods and services that have lessened the drudgery of housework, enhanced consumers' self-confidence and sense of style, and enabled consumers to use their time - a finite resource - in more productive and satisfying ways» therefore, has increased the standard of living for great number of societies (Wilkie, 2006), As he cites Ralph Breyer «Marketing is not primarily a means for garnering profits for individuals. It is, in the larger, more vital sense, an economic instrument used to accomplish indispensable social ends... A marketing system designed solely for its social effectiveness would move goods with a minimum of time and effort to deficit points. In doing so, it would also provide fair compensation, and no more, for the efforts of those engaged in the activity. At the same time, it would provide the incentive needed to stimulate constant improvements in its methods. These are the prime requisites of social effectiveness» (1934). Though at the same time, where the products come from, those societies have not been given much. Recently, marketing has damaged societies by marketing products which are a danger to the health of consumers 
(cigarettes, alcohol), environment (plastic bottles, big cars) and society (types of movies, music) as a whole. Recycling of products was recently taken into consideration as the world has faced the number of dangers (Holbrook, 2006) and rather than increasing the quality of life, it has decreased it (Berry and Mirabito, 2006). Today sustainability marketing has taken a rise due to ever-changing climate and environment. Green marketing has increased which encourages recycling products in order to save the environment.

Literature Review. Wang et al. (2015) in their study «The Journal of Consumer Research At 40: A Historical Analysis», reviewed a corpus of 2031 articles which covers 40 volumes from June 1974 to April 2014. Their study used texting mining and probabilistic topic modelling (LDA), through it 16 topics were attained. Methodological issues and family decision-making had decreased over time, whereas, "consumer culture» has continuously increased; «social identity and influence», "emotional decisionmaking» and "self-control and goals» have started to increase recently. According to the assumption made by the authors for future trends in consumer behaviour areas such as self-control and goals, emotions in the consumer decision process, and consumer culture will be seeing an increase. Cho et al. (2017) in their study «Popular Research Topics in Marketing Journals, 1995-2014» applied topic modelling together with social network analysis to study the evolution of marketing research direction from 1995 to 2014. They covered 25 marketing journals which accumulated to a corpus of 17,249 articles. Using topic modelling, the study had categorized 13 groups which consisted of 100 topics. They found that the "value networks» group which include topics of the value chain, business model, and business networks covered $11.27 \%$ of all the topics between the period of 20 years. Advertising and branding group was the most popular 20 years back but has taken a great fall since then. Three groups have been found to have increased in popularity in recent years. "Social norms», "Psychology and behaviour», and "Competence». They found the most impactful journals in marketing are the ones which have a diverse range of topics, and rest of the journals have a specific field of marketing which it focuses on. The authors also found co-author communities among journals and topics. Bibliometric analysis is one of the well-known quantitative method used today for analysing science (Wu et. al., 2016). Through bibliometric analysis, one can find research direction and well-known topics in the research literature. Initially, it was applied in various disciplines in science and humanities (Price, 1976; White and McCain, 1989; Wiberley, 2003). And later the application of bibliometric expanded to social science disciplines (Glanzel, 1996) such as marketing (Arnott, 2007), international business (Fetscherin et al., 2010), communications (Pasadeos et al., 1999), advertising (Kim and McMillan, 2008), and international management (Acedo and Casillas, 2005). Contemporarily, the most used method is coword analysis, which was initially proposed in the 1970s (Yang et al, 2012). Co-word analysis's main idea is described as when there are two or more keywords which represent a topic have appeared in the same article have an important relationship (An \& Wu, 2011). And as the co-occurrence between the two keywords increases, the relationship becomes stronger. Co-word analysis has been applied by the number of studies in different domains. The study carried out by Dehdarirad and others (2014) used coword analysis and text mining technique to map the intellectual structure of Scientometrics. The current study will make use of co-word analysis to find out the co-occurrence of keywords to see if there have been any changes after the publication of the book.

Methodology and research methods. For the current study, VOSviewer software was used for carrying out co-word (keyword co-occurrence) analysis. This software package has been developed for creating, visualizing, and exploring bibliometric maps of the data (Van Eck \& Waltman, 2010). VOSviewer is currently being used for analysing all sort of bibliometric network data, such as text mining, keyword co-occurrence, co-authorship, citation, bibliographic coupling, or co-citation mapping (Van Eck, 2011). Data for the study has been gathered via SCOPUS. The currently collected data consists of 11 journals which were selected based on the top Journals of Marketing at the SCOPUS citation index, 
which accounts for a total of 3,618 articles. The list of journals, impact factors, number of articles and citation scores has been shown in Table 1.

Table 1. Scope of the Study

\begin{tabular}{|c|c|c|c|c|c|c|}
\hline \multirow[b]{2}{*}{ No. } & \multirow{2}{*}{ Journal Name } & \multirow{2}{*}{ Sitecore } & \multirow{2}{*}{$\begin{array}{c}\text { Impact } \\
\text { Factor } \\
2016\end{array}$} & \multirow{2}{*}{$\begin{array}{c}5 y r \\
\text { Impact } \\
\text { Factor }\end{array}$} & \multicolumn{2}{|c|}{$\begin{array}{c}\text { Number of } \\
\text { Articles }\end{array}$} \\
\hline & & & & & $\begin{array}{l}2001- \\
2005\end{array}$ & $\begin{array}{l}2007- \\
2011\end{array}$ \\
\hline 1 & Journal of Interactive Marketing & 7.64 & 5.026 & 7.767 & 119 & 123 \\
\hline 2 & Journal of Supply Chain Management & 7.64 & 5.789 & & 109 & 126 \\
\hline 3 & Journal of Marketing & 6.55 & 5.3 & 9 & 174 & 279 \\
\hline 4 & Journal of the Academy of Marketing Science & 6.36 & 5.888 & & 153 & 238 \\
\hline 5 & Academy of Management Perspectives (Executive) & 5.45 & 4.943 & 7.156 & 0 & 30 \\
\hline 6 & Journal of Consumer Research & 5.04 & 3.8 & & 270 & 360 \\
\hline 7 & Journal of Marketing Research & 5 & 3.7 & 5.3 & 210 & 379 \\
\hline 8 & Journal of Retailing & 4.64 & 3.772 & 4.613 & 122 & 182 \\
\hline 9 & Journal of Purchasing and Supply Management & 4.61 & 3.24 & 4.856 & 46 & 99 \\
\hline 10 & Journal of International Marketing & 4.44 & 3.7 & 4.9 & 119 & 100 \\
\hline \multirow[t]{3}{*}{11} & Journal of World Business & 4.43 & 3.758 & 4.541 & 52 & 120 \\
\hline & & & & & 1582 & 2036 \\
\hline & & & & & \multicolumn{2}{|c|}{3618} \\
\hline
\end{tabular}

Sources: developed by the authors through the SCOPUS database

The data consists of articles from the year 2001 to 2005 and 2007 to 2011, the years 2001-2005 were selected as the five years prior to the publication year (2006) of the book, 2007 to 2011 are selected as the five years following the book publication to see if there were any changes in comparison to the years prior to the publication of the book. Years beyond 2011 were not chosen in order to rule out alternative factors which might influence the marketing environment in academics and practices. The study follows the following process in order to come to a conclusion. Firstly, data is collected in order to carry out the analysis. Secondly, keyword co-occurrence analysis is performed to unveil the keywords. Thirdly, high-frequency keywords are selected through which the fourth step takes place for developing the co-occurrence matrix, and finally interpretation of the topics structured in the social network analysis. All the steps are performed similarly to both sets of data from 2001-2005 and 2007-2011. The comparison of the results will show whether if any changes have taken place since the call for reform in 2006. From the years 2001-2005, 1290 keywords were extracted. And from years 2007-2011, 4081 keywords are extracted. A minimum number of occurrences of a keyword was set to 8 , as mentioned by Chen and colleagues (2016) that topics with occurrences below 8 does not have much importance. Years 2001-2005, which resulted in 41 keywords that met the threshold. And years 2007-2011 resulted in 85 keywords that met the threshold (Table 2).

Results. Through the keywords which are given by the authors, the content of the paper can be extracted. And through the co-occurrence frequency, the themes can be extracted. Table 2 shows the list of keywords from both periods and their co-occurrence frequencies. For period before the book publication 2001-2005, the top tend frequencies are supply chain management (53), marketing (47), Customer Satisfaction (47), industrial management (44), costs (26), societies and institutions (24), industrial economics (21), purchasing (20), electronic commerce (19), and competition (18). And for period after the book publication 2007-2011, the top tend frequencies are supply chain management (97), advertising (48), retailing (40), customer relationship marketing (31), customer satisfaction (31), consumer behaviour (30), innovation (28), market orientation (25), marketing strategy (24), and 
performance (24). It can easily be depicted that just three of the top ten topics are the same before and after the publication and rest have either changed or have become less attractive.

Table 2. Keywords from 2001-2005 \& 2007-2011 with the frequency of Co-occurrences

\begin{tabular}{|c|c|c|c|c|c|c|c|c|}
\hline \multicolumn{3}{|c|}{ 2001-2005 } & \multicolumn{6}{|c|}{ 2007-2011 } \\
\hline No & Keyword & Freq. & No & Keyword & Freq. & No & Keyword & Freq \\
\hline 1 & 2 & 3 & 4 & 5 & 6 & 7 & 8 & 9 \\
\hline 1 & $\begin{array}{l}\text { supply chain } \\
\text { management }\end{array}$ & 53 & 1 & supply chain management & 97 & 46 & communication & 10 \\
\hline 2 & customer satisfaction & 47 & 2 & advertising & 48 & 47 & culture & 10 \\
\hline 3 & marketing & 47 & 3 & retailing & 40 & 48 & customer equity & 10 \\
\hline 4 & industrial management & 44 & 4 & $\begin{array}{l}\text { customer relationship } \\
\text { management }\end{array}$ & 31 & 49 & institutional theory & 10 \\
\hline 5 & costs & 26 & 5 & customer satisfaction & 31 & 50 & international marketing & 10 \\
\hline 6 & $\begin{array}{l}\text { societies and } \\
\text { institutions }\end{array}$ & 24 & 6 & consumer behaviour & 30 & 51 & learning & 10 \\
\hline 7 & industrial economics & 21 & 7 & innovation & 28 & 52 & marketing-finance interface & 10 \\
\hline 8 & purchasing & 20 & 8 & market orientation & 25 & 53 & motivation & 10 \\
\hline 9 & electronic commerce & 19 & 9 & marketing strategy & 24 & 54 & new products & 10 \\
\hline 10 & competition & 18 & 10 & performance & 24 & 55 & resource-based view & 10 \\
\hline 11 & sales & 18 & 11 & pricing & 23 & 56 & social networks & 10 \\
\hline 12 & decision making & 14 & 12 & China & 21 & 57 & affect & 9 \\
\hline 13 & information technology & 14 & 13 & relationship marketing & 21 & 58 & brand personality & 9 \\
\hline 14 & pricing & 14 & 14 & trust & 21 & 59 & customer value & 9 \\
\hline 15 & strategic planning & 14 & 15 & $\begin{array}{l}\text { corporate social } \\
\text { responsibility }\end{array}$ & 18 & 60 & electronic commerce & 9 \\
\hline 16 & internet & 13 & 16 & new product development & 17 & 61 & event study & 9 \\
\hline 17 & problem solving & 13 & 17 & service quality & 17 & 62 & information processing & 9 \\
\hline 18 & performance & 12 & 18 & meta-analysis & 16 & 63 & knowledge & 9 \\
\hline 19 & $\begin{array}{l}\text { supply-chain } \\
\text { management }\end{array}$ & 12 & 19 & service-dominant logic & 16 & 64 & marketing & 9 \\
\hline 20 & industrial relations & 11 & 20 & word of mouth & 16 & 65 & sales management & 9 \\
\hline 21 & mathematical models & 11 & 21 & branding & 15 & 66 & strategy & 9 \\
\hline 22 & supply chain & 11 & 22 & internet & 15 & 67 & attention & 8 \\
\hline 23 & $\begin{array}{l}\text { supply chain } \\
\text { management }\end{array}$ & 11 & 23 & loyalty & 15 & 68 & attitudes & 8 \\
\hline 24 & investments & 10 & 24 & satisfaction & 15 & 69 & conjoint analysis & 8 \\
\hline 25 & logistics & 10 & 25 & competition & 14 & 70 & construal level & 8 \\
\hline 26 & outsourcing & 10 & 26 & decision making & 14 & 71 & ethics & 8 \\
\hline 27 & relationship marketing & 10 & 27 & sustainability & 14 & 72 & financial decision making & 8 \\
\hline 28 & $\begin{array}{l}\text { Buyer-seller } \\
\text { relationships }\end{array}$ & 9 & 28 & customer lifetime value & 13 & 73 & game theory & 8 \\
\hline 29 & consumer behaviour & 9 & 29 & e-commerce & 13 & 74 & governance & 8 \\
\hline 30 & contracts & 9 & 30 & financial performance & 13 & 75 & incentives & 8 \\
\hline 31 & retailing & 9 & 31 & internationalization & 13 & 76 & marketing capabilities & 8 \\
\hline 32 & supplier relations & 9 & 32 & services & 13 & 77 & national culture & 8 \\
\hline 33 & supply chains & 9 & 33 & brand equity & 12 & 78 & promotion & 8 \\
\hline 34 & $\begin{array}{c}\text { economic and social } \\
\text { effect }\end{array}$ & 8 & 34 & brand management & 12 & 79 & risk management & 8 \\
\hline 35 & food products & 8 & 35 & emerging markets & 12 & 80 & scale development & 8 \\
\hline
\end{tabular}


Continue table 2

\begin{tabular}{|c|c|c|c|c|c|c|c|c|}
\hline $\mathbf{1}$ & $\mathbf{2}$ & $\mathbf{3}$ & $\mathbf{4}$ & $\mathbf{5}$ & $\mathbf{6}$ & $\mathbf{7}$ & $\mathbf{8}$ & $\mathbf{9}$ \\
\hline 36 & inventory control & 8 & 36 & context effects & 11 & 81 & $\begin{array}{c}\text { small to medium-sized } \\
\text { enterprises }\end{array}$ & 8 \\
\hline 37 & product design & 8 & 37 & customer loyalty & 11 & 82 & social influence & 8 \\
\hline 38 & product development & 8 & 38 & customer orientation & 11 & 83 & supply chain & 8 \\
\hline 39 & quality control & 8 & 39 & distribution management & 11 & 84 & value & 8 \\
\hline 40 & $\begin{array}{c}\text { research and } \\
\text { development }\end{array}$ & 8 & 40 & emotions & 11 & 85 & willingness to pay & 8 \\
\hline 41 & satisfaction & 8 & 41 & export performance & 11 & & & \\
\hline & & & 42 & internet marketing & 11 & & & \\
\hline & & & 43 & outsourcing & 11 & & & \\
\hline & & & 44 & promotions & 11 & & & \\
\hline & & & 45 & purchasing & 11 & & & \\
\hline
\end{tabular}

Sources: developed by the authors through VOSviewer software results of keyword co-occurrences

Through social network analysis, we are able to attain the social network map of the co-occurrence matrix which is represented in Figure 1.

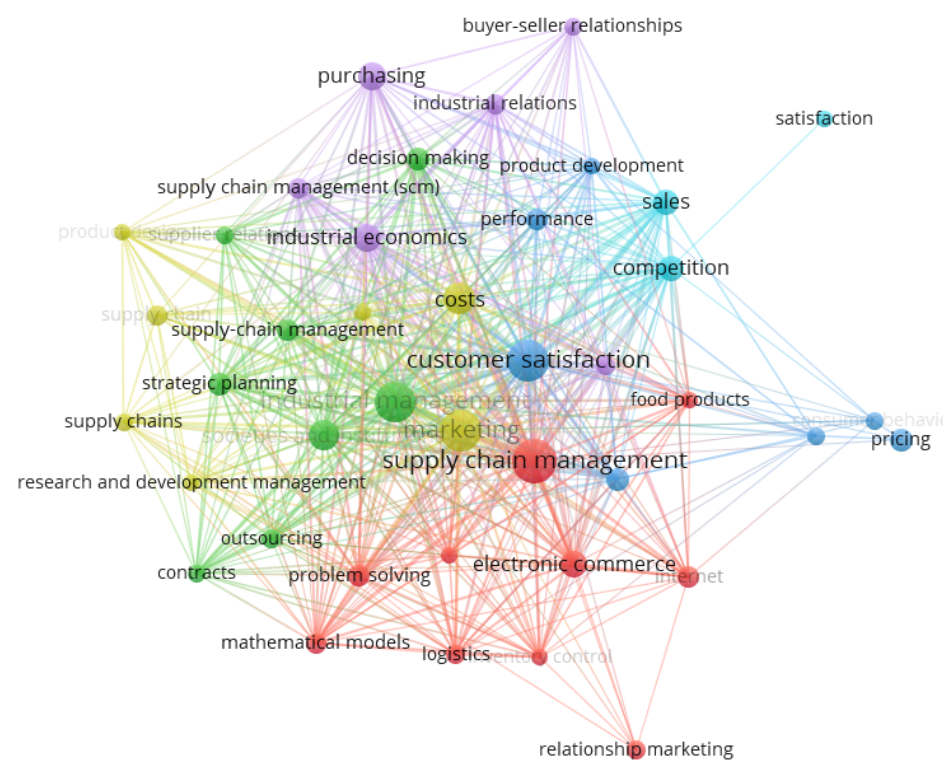

Figure 1. Social network map of co-occurrence matrix 2001-2005

Sources: developed by the authors through VOSviewer software.

It reveals the relationship which themes have with one another. The size of the spheres represents the frequency of keywords used in the corpus, the larger the size of the sphere, the higher the frequency. The relationship between two words is represented by the lines connecting them, the thicker the line is the stronger the relationship. In the social network map, it can be seen biggest sphere is of supply chain management which means that it has the most frequency of the words, along with it, marketing, customer satisfaction and industrial management have high frequencies. The thickness of the lines shows the closeness of the relationship, for example, a social network map of co-occurrence matrix of years 2001-2005 (Figure 1) shows supply chain management, marketing, customer satisfaction, and 
industrial management show thick lines connecting them showing the close relationships they have between them. On the contrary, there are keywords represented by a smaller sphere meaning they are low in frequency. And there might be either one line (satisfaction) or few lines (pricing) connecting them to other keywords, which indicates that these keywords are in the border of the research area and might be connected through a keyword which is high in frequency. Social network map of the co-occurrence matrix of years 2007-2011 (Figure 2) shows that supply chain management has the highest frequency as its sphere is the largest.

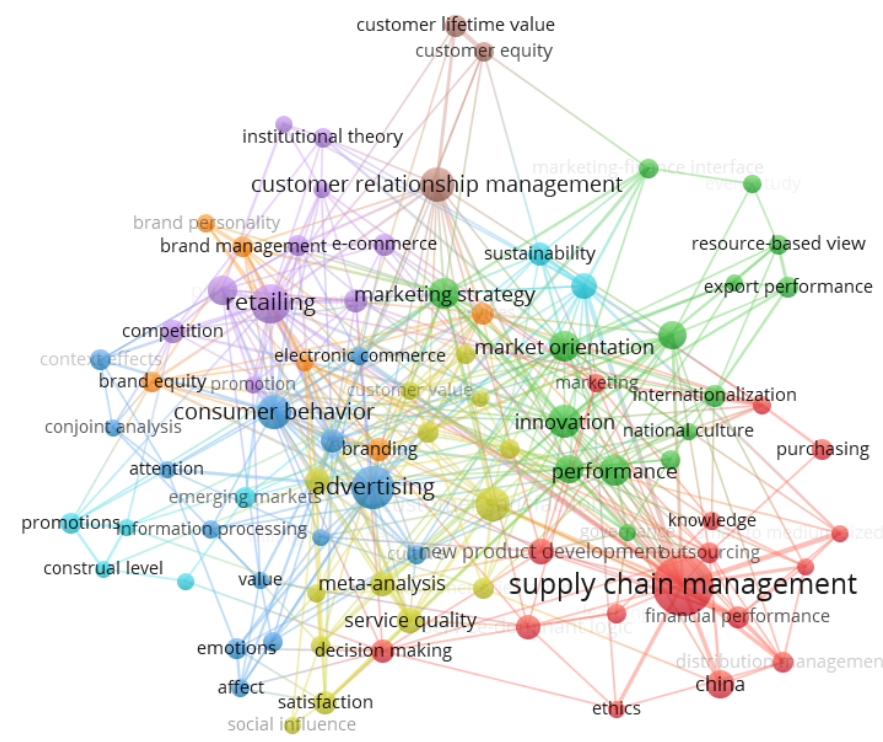

Figure 2. Social network map of co-occurrence matrix 2007-2011

Sources: developed by the authors through VOSviewer software

Showing that supply chain management still the mainstream topic for the researchers. Advertising is the second highest frequency keyword without having a relationship with supply chain management. Retailing which is the third highest frequency keyword has a strong relationship with supply chain management and with the fourth (consumer behaviour) and fifth (customer relationship management) highest frequency keywords. Along with that, most of the high-frequency keywords have been replaced with new keywords which did not exist in the period before the call for reform. Co-word analysis helped to find the co-occurrences of the important keywords. Through which the keywords have been arranged according to the themes of the book.

Insight-centric marketing (ICl): looking from the list of new keywords, motivation, trust, customer loyalty, customer orientation, emotions, customer relationship management, market orientation and value are topics which have been brought to attention since the publication. These topics are related to marketing being customer-centric rather than process-centric. The whole concept of insight-centric marketing is to develop strategies which are customer based and not process-centric.

Relationship of marketing with other organizational functions: according to the book, marketing lacks integration and interests in the other functions of the organization. In order for marketing to be successful marketers needs to have knowledge of other functions and integrate them into the marketing process. Since the publication following keywords (topics) can be seen corporate social responsibility, sales 
management, financial performance, internationalization, distribution management, export performance, marketing-finance interface, sales management, financial strategy, and purchasing. Marketing must involve other functions of an organization in its strategy development process in order to come up with an effective and hybrid strategy which would show the strength of the organization working as a whole. It can be settled that research has taken a turn towards bringing other business functions into marketing.

Consumer resistance to marketing / excessive marketing spending: as marketing has started to become a target for the consumer due to mass marketing and its negative impacts on the consumers, there is a need for bringing change into the marketing is practised. Few keywords which have shown up since the book's publication which would show that academicians have started to look towards this issue are ethics, culture, and communication. Marketing practices must be carried out within its limits so that they do not bring any harm to the consumers, society, or the environment. Accountability of marketing (ROMI): As mentioned in the book (Sheth \& Sisodia, 2006), marketing needs to take responsibility for its accountability, not the financial department. There are several keywords which have been extracted that comply with the accountability of marketing within a firm. Customer lifetime value, financial performance, brand equity, customer equity, marketing-finance interface, customer value, financial decision making, and export performance. There yet needs to be more work done on these topics as the customers change their minds in this rapidly changing global market.

Future of marketing/marketing paradigms / mental models: as the main concept of the book is a call for reform. The number of scholars has mentioned that there is a need for reform, a shift in marketing paradigm, or a need for new mental models for marketing. There seem too few keywords which have popped up since the publication which are: service-dominant logic, meta-analysis, resource-based view, and construal level. As for the future of marketing, a number of keywords could be seen as towards development of marketing practices, marketing capabilities, and of current theories of marketing.

Marketing technology: contemporary world has reached a technological age which was once never imaginable. Marketing has been gifted with the great number of technological tools which it could use for its benefit. Keywords which have been brought to light are innovation, internet marketing, marketing capabilities, and social networks. Though internet marketing and social networks have been around, yet the importance has been shown after the publication of the book. There seems to be a need still in marketing technology.

Marketing education: marketing education is one of the most important aspects of marketing discipline as it forms the bases for the new scholars. As Chipp and colleagues (2006) mentioned in the book, courses on ethics and consumer behaviour are not provided in all universities around the world. Results show that knowledge, learning, and meta-analysis keywords have gained focus. One must have a substantial amount of knowledge in order to carry out research on marketing or even to put the theory into practice. As it can be seen through these keywords that there has been a change in the scholarly world towards marketing education.

Societal impact and sustainability through marketing: societal impact and sustainability have a great impact on the image of marketing and is important for marketing as a discipline. Corporate social responsibility, sustainability, ethics, culture, national culture, and social influence are key keywords (topics) which have been mentioned in the articles published after the book's publication. Marketing has to take societal impact and sustainability more seriously if it is to win back consumers. Regardless of taking five years of the period before and after the publication of the book, the time period was selected due to checking the impact book would have on the following years. The years could have been extended but due to having doubt that the changes might be made from some other reasons, the years were kept to five each. One of the main limitations is that our work is based on one book which was published in 2006 by well-known scholars in marketing discipline and was kept as the bases of the study. 
Conclusions. As of now, there are number of new topics which have been introduced in the marketing literature such as brand relationship (Aggarwal \& McGill, 2012), brand hate (Zarantonello, 2016), brand love (Batra et al., 2012), brand divorce (Fiona et al., 2012), and others as the marketing concept is evolving with other disciplines and adapting to other parts of business activities. We believe that it is important to consider the topics which have been acknowledged by the book due to the importance they hold for marketing's future. We would encourage researchers to carry out research on finding new mental models for the marketing discipline as noted by Sheth and Sasodia (2006) because marketing's future depends on it due to base models today cannot be applied in the ever-changing markets.

Author Contributions: M.T. as the first author of the paper conceived and designed the analysis, collected data, performed analysis, and wrote the paper. N.G., as the main supervisor to the paper, helped with designing the paper and its framework, aided with the collection of data, and edited and reviewed the paper at each step. M.G. helped with the methodology, data collection and aided mainly with the type of analysis and tools. Conceptualization of the paper was done by M.T., and N.G.; methodology, was written by M.T., with the aid of the other two authors.; software used for carrying out analysis was VOSviewer, the selection of analysis tools are credited to M.G.; validation, of the study, was done by M.T., N.G., and M.G.; formal analysis was carried out by M.T.; investigation, M.T. and N.G.; resources M.T. and N.G.; data curation, N.G. and M.G.; writing-original draft preparation was done by M.T.; writing-review and editing, N.G.; visualization, M.T.; supervision, N.G.; project administration, N.G.

\section{References}

Acedo, J., \& Casillas, C. (2005). Current paradigms in the international management field: An author co-citation analysis. International Business Review, 14(5), 619-639.

Aggarwal, P., \& McGill, A. L. (2012). When brands seem human, do humans act like brands? Automatic behavioral priming effects of brand anthropomorphism. Journal of Consumer Research, 39(2), 307-323.

Ambler, T. (2006). Questions Marketers Need to Answer. In Does Marketing Need Reform? Fresh Perspectives on the Future. (pp. 172-179). New York: M. E. Sharpe, Inc.

An, X.Y., \& Wu, Q.Q. (2011). Co-word analysis of the trends in stem cells field based on subject heading weighting, Scientometrics, 88. 133-144.

Arnott, D. C. (2007). Research on trust: A bibliography and brief bibliometric analysis of the special issue submissions. European Journal of Marketing, 41(9), 1203-1240.

Batra, R., Ahuvia, A., \& Bagozzi, R. P. (2012). Brand love. Journal of Marketing, 76(2), 1-16.

Berry, L. L., and Mirabito A. M. (2006). Recapturing Marketing's Mission. In Does Marketing Need Reform? (pp. 295-299). New York, NY: M.E. Sharpe.

Brady, M. K., \& Cronin, J. J. (2001). Customer Orientation. Journal of Service Research, 3(3), 241-251.

Brown, S. (2006). Does Reform Need Reform. In Does Marketing Need Reform? (pp. 57-63). New York, NY: M.E. Sharpe.

CAS. Casualty Actuarial Society. (2001). Retrieved Online. Websites:

http://www.casact.org/CONEDUC/specsem/erm/2001/handouts/handouts.htm

Chalmeta, R. (2006). Methodology for customer relationship management. Journal of Systems and Software, 79(7), 10151024. doi:j.jss.2005.10.018

Chen, Z., \& Dubinsky, A. J. (2003). A conceptual model of perceived customer value in e-commerce: A preliminary investigation. Psychology and Marketing, 20(4), 323-347. doi:10.1002/mar.10076

Chipp, K., Hoeing, S. and Nel, D. (2006). What Can Industrializing Countries Do to Avoid the Need for Marketing Reform?. In Does Marketing Need Reform? (pp. 222-228). New York, NY: M.E. Sharpe.

Cho, Yung-Jan, Pei-Wen Fu, And Chi-Cheng Wu. (2017), "Popular Research Topics In Marketing Journals, 1995-2014." Journal Of Interactive Marketing 40: 52-72. Doi:10.1016/J.Intmar.2017.06.003.

Cronin J.J., Skinner S.J. (2015) The Marketing-Finance Interface: The Impact of Marketing Objectives and Financial Conditions on Retail Profitability. In: Malhotra N. (eds) Proceedings of the 1985 Academy of Marketing Science (AMS) Annual Conference. Developments in Marketing Science: Proceedings of the Academy of Marketing Science. Springer, Cham.

Dehdarirad T., Villarroya A., Barrios M. (2014). Research trends in gender differences in higher education and science: a coword analysis, Scientometrics, 101. 273-290.

Fetscherin, M., Voss, H., \& Gugler, P. (2010). 30 years of foreign direct investment to China: An interdisciplinary literature review. International Business Review, 19(3), 235-246. 


\section{Taqi, N. Gurkaynak, M. Gencer. Marketing Concept Evolution: a Bibliometrics Co-occurrence Analysis}

Fiona, S., Meamber, L., \& Hall, R. (2012). Introspecting the spiritual nature of a brand divorce. Journal of Business Research, 65(4), 520-526.

Glanzel, W. (1996). A bibliometric approach to social sciences, national research performances in 6 selected social science areas, 1990-1992. Scientometrics, 35(3), 291-307.

Holbrook, M. B. (2006). Does Marketing need Reform School? On the Misapplication of Marketing to the Education of Marketers. In Does Marketing Need Reform? (pp. 265-269). New York, NY: M.E. Sharpe.

Johansson J.K. (2006). Why Marketing Needs Reform. In Does Marketing Need Reform? (pp. 37-44). New York, NY: M.E. Sharpe.

Keller, K. L. \& Kotler, P. (2006). Holistic Marketing. In Does Marketing Need Reform? Fresh Perspectives on the Future. (pp. 300-305). New York: M. E. Sharpe, Inc.

Kim, J., \& McMillan, S. (2008). Evaluation of internet advertising research: A bibliometric analysis of citations from key sources. Journal of Advertising, 37(1), 99-112.

Kotler, P. and Armstrong, G. (1996), Principles of Marketing, 7th edition ed., Englewood Cliffs, NJ: Prentice-Hall.

Laczniak, G.R. and Murphy, P.E. (1993) Ethical Marketing Decisions: The Higher Road. Naadham heights, MA: Allyn \& Bacon.

Malhotra. N.K., Wu, L. and Allvine, F.C. (2006). Marketing Reform: The Case of Excessive Buying. In Does Marketing Need Reform? (pp. 45-54). New York, NY: M.E. Sharpe.

Meldrum, M.J. and R. Palmer (1998), "The Future of Marketing in Industrial and Technological Organizations," Working paper, Cranfield University.

Melkman, A. (2004), "Increasing Marketing's Influence in the Boardroom," MCE Knowledge, http://64.233.179.104/search?q=cache:_LrjxMHFgFwJ:www.mce.be/knowledge/394/7+melkman+ boardroom\&hl=en.

Pasadeos, Y., Renfro, R., \& Hanily, M. (1999). Influential authors and works of the public relations scholarly literature: A network of recent research. Journal of Public Relations Research, 11(1), 29-52.

Pfeffer, J. (1994), Competitive Advantage Through People. Boston: Harvard Business School Press.

Price, D. (1976). A general theory of bibliometric and other cumulative advantages processes. Journal of the American Society for Information Science, 27(5-6), 292-306.

Raju, J. S. (2006). Revitalizing the Role of Marketing in Business Organizations: What Can Poor Academics Do to Help?. In Does Marketing Need Reform? (pp. 261-264). New York, NY: M.E. Sharpe.

Sheth J.N., Sisodia R.S., and Barbulescu A. (2006). The Image of Marketing. In Does Marketing Need Reform? (pp. 26-36). New York, NY: M.E. Sharpe.

Sheth, J. N. \& Sisodia, R. S. (2006b). How to Reform Marketing. In Does Marketing Need Reform? Fresh Perspectives on the Future. (pp. 324-333). New York: M. E. Sharpe, Inc

Sheth, J. N., \& Sisodia, R. (2006a). Does marketing need reform?: fresh perspectives on the future. Armonk, NY: M.E. Sharpe.

Shipley, D. (1994), "Achieving Cross-Functional Co-Ordination for Marketing Implementation," Management Decision, 32 (October), $17-20$.

Simms, J. (2003), "How to Drive Business Success ... and Your Own Career," Marketing, September 18, 22-23.

Sisodia, R. and Backer, A. (2004), "Cybermarketing and the Tragedy of the Commons: An Environmental Policy Perspective,"

in Research Reaching New Heights, Proceedings of the AMA Marketing and Public Policy Conference, Salt Lake City, Utah.

Chicago: American Marketing Association.

Smith, J. W. (2004a), "Consumer Resistance to Marketing," paper presented at the symposium Does Marketing Need Reform? Bentley College, Boston.

Smith, J.W. (2004b). Consumer Resistance to Marketing Reaches All-Time High, Marketing Productivity Plummets Presented at American Association of Advertising Agencies (AAAA) Conference. Miami: AAAA.

Smith, J.W. (2006). Coming to Concurrence: Improving Marketing Productivity by Reengaging Resistant Consumers. In Does Marketing Need Reform? (pp. 15-25). New York, NY: M.E. Sharpe.

Stewart, D.W. (2006). Reform, Reclamation, or Improvement: Reinventing Marketing. In Does Marketing Need Reform? (pp.

82-88). New York, NY: M.E. Sharpe.

Urban G.L. (2006). Customer Advocacy: A New Paradigm for Marketing?. In Does Marketing Need Reform? (pp. 119-125).

New York, NY: M.E. Sharpe.

Van Eck, N.J. (2011). Methodological advances in bibliometric mapping of science. PhD thesis, Erasmus University Rotterdam.

Van Eck, N.J., \& Waltman, L. (2010). Software survey: VOSviewer, a computer program for bibliometric mapping Scientometrics, 84(2), 523-538.

Varadarajan, R. (2006). Musings on the Need for Reform in Marketing. In Does Marketing Need Reform? Fresh Perspectives on the Future. (pp. 270-281). New York: M. E. Sharpe, Inc

Venkatesh, A., and Penaloza, L. (2006). From Marketing to the Market: A Call for Paradigm Shift. In Does Marketing Need Reform? (pp. 134-150). New York, NY: M.E. Sharpe. 


\section{Taqi, N. Gurkaynak, M. Gencer. Marketing Concept Evolution: a Bibliometrics Co-occurrence Analysis}

Wang, Xin Shane, Neil T. Bendle, Feng Mai, And June Cotte (2015), "The Journal Of Consumer Research At 40: A Historical Analysis," Journal Of Consumer Research, 42, 1, 5-18.

White, H. D., \& McCain, K.W. (1989). Bibliometrics. Annual Review of Information Science and Technology, 24, 119-186.

Wiberley, S. E. (2003). A methodological approach to developing bibliometric models of types of humanities scholarship. The Library Quarterly, 73(2), 121-159.

Wilkie, W. L. (2006). The World of Marketing Though: Where Are We Heading?. In Does Marketing Need Reform? (pp. 239247). New York, NY: M.E. Sharpe.

Wind, Y.J. (2006). Challenging the Mental Models of Marketing. In Does Marketing Need Reform? (pp. 91-104). New York, NY: M.E. Sharpe.

Winer, R.S. (2006). Does Marketing Need Reform? Personal Reflections. In Does Marketing Need Reform? (pp. 78-81). New York, NY: M.E. Sharpe.

Wu, D.S., Xie, Y.J., Dai, Q.Z., Li, J.P. (2016). A systematic overview of operations research/ management science research in Mainland China: Bibliometric analysis of the period 2001-2013, Asia-Pacific Journal of Operational Research, forthcoming. 673.

Yang Y., Wu M., Cui L. (2012). Integration of three visualization methods based on co-word analysis, Scientometrics, 90. 659-

Zarantonello L., Romani S., Grappi S., Bagozzi R. P., (2016) "Brand hate", Journal of Product \& Brand Management, Vol. 25 Issue: 1, pp.11-25, https://doi.org/10.1108/JPBM-01-2015-0799

Мухаммад Такі, Ph.D., Ізмірський університет економіки (Туреччина);

Нілеун Гуркайнак, Ізмірський університет економіки (Туреччина);

Мехмет Генцер, доцент, Ізмірський університет економіки (Туреччина).

Еволюція маркетингової концепції: бібліометричний аналіз

У статті розелянуто еволюцію розвитку концепції маркетингу початку нового тисячоліття. Авторами проаналізовано реакцію науковців, що досліджують питання маркетингу, на реформи 2006 року у Туреччині. Головною метою статті є визначення напрямів розвитку маркетингової концепції до впровадження рефрорм, аналіз впливу впровадження реформ на зміну маркетингової концепції в Туреччині. Авторами зазначено, що причиною впровадження реформ у науковому маркетинговому колі стало наявність ряду проблем, що потурбували пошуку механізмів їх вирішення. Відповідно до мети, авторами проведено порівняльний аналіз актуальних напрямів маркетингових дослідження до та після впровадження рефрорм. Емпіричне дослідження проведено з використанням бібліометричного підходу, відомого як «аналіз спільних слів». У статті для аналізу спільних слів (за ключовими словами) авторами використано програмне забезпечення VOSviewer. При цьому вихідні данні для дослідження сформовано на основі аналізу науковометричної бази даних SCOPUS. Таким чином, загальна вибірка дослідження становила 3618 статей із означеної тематики, опублікованих у 11 найпопулярніших маркетингових журналах за індексом цитування бази даних SCOPUS. Крім того, до списку маркетингових журналів увійшли журнали, що спеціалізуються на управлінні каналами розподілу та постачанням, поведінкою споживачів, інтерактивним та міжнародним маркетингом. Авторами зазначено, що аналіз ключових слів використаний з метою виявлення тендениії у маркетингових дослідженнях. Так, на основі результатів аналізу ключових слів, авторами розподілено ключові слова за 8 напрямами. Авторами емпірично підтверджено та теоретично обгрунтовано, що впровадження реформ спричинило зміну тенденції еволюції маркетингової концепції. Враховуючи отримані результати, авторами зроблено висновок, що представники турецької маркетингової наукової спільноти в певній мірі відреагували на впровадження реформ. У статті зазначено, що отримані результати дослідження є корисними для оцінки реакції представників маркетингової наукової спільноти на впровадження рефоорм, а також виявлення змін у маркетингових дослідженнях. Крім того, авторами наголошено, що наразі не існує жодного дослідження, яке б дозволило виявити вплив впроваджених рефоорм на маркетингову концепцію та чи спричинило це відповідні ії зміни.

Ключові слова: бібліометрика, аналіз спільних слів, еволюція маркетингу, маркетингова реформа, маркетинг.

Manuscript received: 05.03.2019.

(C) The author(s) 2019. This article is published with open access at Sumy State University. 